\title{
Does conservative treatment must be the first choice in elderly patients with degenerative rotator cuff tears?
}

\author{
O. Şahap Atik, MD (D) \\ President, Turkish Joint Diseases Foundation, Ankara, Turkey
}

The optimal treatment for partial and full-thickness degenerative rotator cuff tears is still unclear, since both conservative and surgical treatments have strengths and weaknesses.

Conservative treatment may predispose patients to continued irreversible tissue degeneration over time. Therefore, rotator cuff tears which can be initially managed as repairable may become irreparable, leading to the need for further treatments and worse results. ${ }^{[1]}$

The cost of rotator cuff repair surgery is high, and the patient-reported and functional outcomes after rotator cuff repair may not be superior to those of non-operative treatment. ${ }^{[2,3]}$ Factors which can decrease the likelihood of a satisfactory result include poor tendon/tissue quality, large or massive tears, poor patient compliance with rehabilitation and restrictions after surgery, and patient age ( $>65$ years). ${ }^{[3]}$

Received: September 03, 2021

Accepted: September 18, 2021

Published online: November 19, 2021

Correspondence: O. Sahap Atik, MD. Turkish Joint Diseases Foundation, Mustafa Kemal Mah., Dumlupınar Bul., 274/2,

C2 Blok, Ofis 5, 06900 Çankaya, Ankara, Türkiye.

E-mail: satikmd@gmail.com

Doi: 10.52312/jdrs.2021.57901

Citation: Atik OŞ. Does conservative treatment must be the first choice in elderly patients with degenerative rotator cuff tears? Jt Dis Relat Surg 2021;32(3):567-568.

02021 All right reserved by the Turkish Joint Diseases Foundation

This is an open access article under the terms of the Creative Commons Attribution-NonCommercial License, which permits use, distribution and reproduction in any medium, provided the original work is properly cited and is not used for commercial purposes (http://creativecommons.org/licenses/by-nc/4.0/).
However, there are certain subpopulations in which surgery is more effective. ${ }^{[4]}$

A recent Cochrane review showed no clinically important benefit to surgery in the treatment of symptomatic, atraumatic rotator cuff tears. ${ }^{[5]}$ Karjalainen et al. ${ }^{[5]}$ found no clinically important differences in pain, function, or health-related quality of life.

A meta-analysis reviewed the evidence on effectiveness of tendon repair in reducing pain and improving function of the shoulder, compared to conservative treatment of symptomatic rotator cuff tear. ${ }^{[6]}$ The authors concluded that there was a limited number of evidence that surgery was not more effective in treating rotator cuff tear than conservative treatment alone. As physiotherapy has less complications and it is less expensive than surgery, a conservative approach is advocated, as the initial treatment modality to rotator cuff tears. ${ }^{[6]}$

Another meta-analysis of randomized trials compared the effectiveness of surgical repair to conservative treatment and subacromial decompression for the treatment of chronic/degenerative tears of the rotator cuff. ${ }^{[7]}$ The surgical repair resulted in significantly improved outcomes compared to either conservative treatment or subacromial decompression alone for degenerative rotator cuff tears in older patients. However, the magnitude of the difference in outcomes between surgery and conservative treatment may be small, and the success rate of conservative treatment may be high. ${ }^{[7]}$

In conclusion, conservative treatment must be the first choice in elderly patients with degenerative rotator cuff tears, depending on the patient's age, lifestyle, level of functional impairment, and compliance with the physiotherapy sessions. 


\section{REFERENCES}

1. Longo UG, Franceschi F, Berton A, Maffulli N, Droena V. Conservative treatment and rotator cuff tear progression. Med Sport Sci 2012;57:90-9.

2. Mather RC 3rd, Koenig L, Acevedo D, Dall TM, Gallo P, Romeo A, et al. The societal and economic value of rotator cuff repair. J Bone Joint Surg [Am] 2013;95:1993-2000.

3. Rotator Cuff Tears: Surgical Treatment Options. Available at: https://www.orthoinfo.org/en/treatment/rotator-cufftears-surgical-treatment-options/

4. Gürpınar T, Polat B, Tekin SB, Esin Polat A, Çarkçı E, Öztürkmen Y. Comparison of early clinical results and re-tear rates of transosseous-equivalent rotator cuff repairs with or without medial knots. Eklem Hastalik Cerrahisi 2019;30:193-200.

5. Karjalainen TV, Jain NB, Heikkinen J, Johnston RV, Page $\mathrm{CM}$, Buchbinder R. Surgery for rotator cuff tears. Cochrane Database Syst Rev 2019;12:CD013502.

6. Ryösä A, Laimi K, Äärimaa V, Lehtimäki K, Kukkonen J, Saltychev M. Surgery or conservative treatment for rotator cuff tear: A meta-analysis. Disabil Rehabil 2017;39:1357-63.

7. Schemitsch C, Chahal J, Vicente M, Nowak L, Flurin $\mathrm{PH}$, Lambers Heerspink F, et al. Surgical repair versus conservative treatment and subacromial decompression for the treatment of rotator cuff tears: A meta-analysis of randomized trials. Bone Joint J 2019;101-B(9):1100-6. 